\title{
Soil fertility - the only possible foundation for more sustainable agriculture
}

\author{
Boris Boincean ${ }^{1 *}$ and David Dent ${ }^{2}$ \\ ${ }^{1}$ Selectia Research Institute for Field Crops, Alecu Russo Balti State University, Republic of Moldova \\ ${ }^{2}$ Chesnut Tree Farmhouse, Forncett End, Norfolk, UK
}

\begin{abstract}
The reductionist approach to intensification of agriculture has created unanticipated economic, ecological and social consequences. Across the steppes, elimination of perennial legumes from the crop rotation and even elimination of crop rotation, large areas under black fallow, and the demise of crop and animal husbandry are draining soil fertility - and in many places loss of the soil itself. Data from long-term field experiments demonstrate the importance of perennial legumes in crop rotation for nitrogen- and wateruse efficiency, accumulation of soil organic matter in deeper soil layers, and resilience in the face of drought.
\end{abstract}

\section{Introduction}

Under pressure from continually falling farm gate prices and continually rising costs, the technological approach to farm intensification has been oriented mainly towards crop yields and profit - without considering its negative environmental and social consequences [1-3]. As a matter of economic survival and sustainabilty, farmers all over the world are seeking an alternative to farming systems that depend on nonrenewable sources of energy and their derivatives (mineral fertilizers, especially nitrogen, pesticides), the mouldboard plough, and irrigation.

Long-term field experiments with crop rotations and continuous monocropping on Chernozem soils of the Balti steppe, Republic of Moldova, demonstrate that, under steppe conditions, replacing perennial vegetation with annual crops, abbreviated crop rotations, and continual disturbance of the soil by ploughing have driven substantial losses of soil organic matter (SOM) and a significant loss of soil fertility.

Sustainability demands a rapid transition to farming in an ecological way - with a different structure of the sown area, no black fallow, less land under row crops and an increase of the area under compact-drilled crops including perennial legumes and grasses, accompanied by re-integration of crop and animal husbandry.

More details about the experiments have been given in our previous publications [4-6].

\section{Results and discussion}

Winter wheat is the mainstay of agriculture on the steppes and soil water stocks during the optimal time for sowing are crucial for achieving high and stable yields. For this reason, early-harvested predecessors offer advantages relative to late-harvested predecessors and continuous wheat. Table 1 presents data on yields and water-use efficiency of winter wheat in crop rotation (after different predecessors) and under continuous wheat.

Consumption of soil water from the $0-200 \mathrm{~cm}$ soil layer by winter wheat is greatest when the crop is sown after early-harvested predecessors (mixture of winter vetch and winter rye for green mass, lucerne in its third year after first cutting, or black fallow) - totalling 186.7$199.6 \mathrm{~mm}$

Water consumption is less after corn-for-grain and under continuous wheat: 147.4-148.5mm. After earlyharvested predecessors, the share of soil water abstracted from the $0-100 \mathrm{~cm}$ soil layer is $50.0-53.6 \%$; and $60.0-$ $70.8 \%$ after corn-for-grain and under continuous cropping.

This means that winter wheat sown after an earlyharvested predecessor is more drought-resistant than continuous wheat and wheat following a late-harvested predecessor. And water-use efficiency is higher in crop rotation, even after a late harvested predecessor, than in continuous monocropping: 331.6-375.9 tonne soil water per tonne of grain and $467.9 \mathrm{t} / \mathrm{t}$, respectively.

We should point out that black fallow offers no advantage over other early-harvested predecessors in terms of yield or water-use efficiency. Besides a loss of a whole year of crops, black fallow contributes less water from precipitation and a substantially greater loss of SOM (Tables 2 and 3); and the lack of soil cover means greater vulnerability to all kinds of soil degradation.

\footnotetext{
* Corresponding author: bboincean@gmail.com
} 
The least amount of soil water accumulated in both 0-100 and 100-200 $\mathrm{cm}$ soil layers accrued under permanent black fallow, followed by winter wheat sown after black fallow in crop rotation.

Meadow has a relatively high capacity to accumulate soil water in both soil layers, which we may attribute to stable soil structure ensuring maximum infiltration of rain and snowmelt and rapid transmissivity throughout the soil profile.

However, winter wheat following a mixture of winter rye and winter vetch for green mass accrues the same amount of water, and winter wheat sown after lucerne in the third year after the first cut accrues a greater share of soil water in the deeper soil layer $(100-200 \mathrm{~cm})$.

Table 1. Water-use efficiency by winter wheat after different predecessors in crop rotation and under continuous monocropping 1994-2018, from the long-term field experiment on crop rotation at Selectia Research Institute of Field Crops, Balti

\begin{tabular}{|c|c|c|c|c|}
\hline $\begin{array}{c}\text { Predecessors in crop } \\
\text { rotation, and continuous } \\
\text { wheat }\end{array}$ & $\begin{array}{c}\text { Soil water consumption during } \\
\text { the growing season from 0- } \\
200 \mathrm{~cm}, \mathrm{~mm}\end{array}$ & $\begin{array}{c}\text { Share of soil water } \\
\text { from 0-200 cm drawn } \\
\text { from 0-100 cm, \% }\end{array}$ & $\begin{array}{c}\text { Yield, } \\
\text { t/ha }\end{array}$ & $\begin{array}{c}\text { Water-use efficiency, } \\
\text { tonne water per tonne } \\
\text { of grain }\end{array}$ \\
\hline Black fallow & 186.7 & 50.0 & 5.63 & 331.6 \\
\hline $\begin{array}{c}\text { Winter vetch and winter } \\
\text { rye for green mass }\end{array}$ & 187.8 & 51.8 & 5.41 & 347.1 \\
\hline $\begin{array}{c}\text { Lucerne, } 3^{\text {rd }} \text { year after } \\
1^{\text {st }} \text { cutting }\end{array}$ & 199.6 & 53.6 & 5.31 & 375.9 \\
\hline Corn-for-grain & 148.5 & 70.8 & 3.96 & 375.0 \\
\hline $\begin{array}{c}\text { Continuous winter } \\
\text { wheat }\end{array}$ & 147.4 & 60.0 & 3.15 & 467.9 \\
\hline
\end{tabular}

Table 2. Soil water accumulation during fall-winter-spring $(\mathrm{mm})$ under black fallow, meadow, and winter wheat after different predecessors in crop rotation and under permanent monocropping: means for 1994-2018 in the long-term field experiment at Selectia RIFC

\begin{tabular}{|c|c|c|c|c|c|}
\hline \multicolumn{3}{|c|}{ Experimental plots } & $\begin{array}{c}\text { Soil } \\
\text { layers, } \\
\mathrm{cm}\end{array}$ & $\begin{array}{c}\text { Soil water accumulation } \\
\text { during fall-winter-spring, } \\
\mathrm{mm}\end{array}$ & $\begin{array}{c}\text { Share of } 0-100 \mathrm{~cm} \text { layer in } \\
\text { total water accumulation in } 0 \text { - } \\
200 \mathrm{~cm} \text { layer, } \%\end{array}$ \\
\hline \multirow{2}{*}{\multicolumn{3}{|c|}{ Black fallow }} & $0-100$ & +17.4 & \multirow{2}{*}{59.8} \\
\hline & & & $0-200$ & +29.1 & \\
\hline \multirow{2}{*}{\multicolumn{3}{|c|}{ Meadow }} & $0-100$ & +78.5 & \multirow{2}{*}{55.6} \\
\hline & & & $0-200$ & +141.2 & \\
\hline \multirow{8}{*}{$\begin{array}{l}\text { Winter } \\
\text { wheat }\end{array}$} & \multirow{6}{*}{ Crop rotation } & \multirow[t]{2}{*}{ after black fallow } & $0-100$ & +30.2 & \multirow{2}{*}{46.7} \\
\hline & & & $0-200$ & +64.7 & \\
\hline & & \multirow{2}{*}{$\begin{array}{l}\text { after winter vetch } \\
\text { and winter rye for } \\
\text { green mass }\end{array}$} & $0-100$ & +85.2 & \multirow{2}{*}{63.7} \\
\hline & & & $0-200$ & +133.8 & \\
\hline & & after lucerne in $3 \mathrm{rd}$ & $0-100$ & +75.2 & \multirow{2}{*}{55.1} \\
\hline & & year after first cut & $0-200$ & +136.6 & \\
\hline & \multirow{2}{*}{$\begin{array}{c}\text { Continuous } \\
\text { wheat }\end{array}$} & \multirow{2}{*}{ winter wheat } & $0-100$ & +89.1 & \multirow{2}{*}{58.0} \\
\hline & & & $0-200$ & +153.5 & \\
\hline
\end{tabular}

Table 3 illustrates lesser accumulation ofsoil water under corn-for-grain, especially in drought conditions. In the crop rotation with lucerne, the resilience of corn-forgrain under drought conditions is determined by the capacity of root system to use water from deeper soil layers - the share of the $0-100 \mathrm{~cm}$ soil layer in the total amount of soil moisture accumulation was the lowest in the crop rotation with lucerne $(55.8 \%)$ relative to other crop rotations in the drought conditions of 2015.

Yields of winter wheat and corn-for-grain are closely related to the capacity of soil to provide their water requirements, especially in drought conditions - and black fallow has the lowest capacity to accumulate soil water (Table 4).

Under drought conditions, the greatest yields of both winter wheat and corn-for-grain were obtained in crop rotation with perennial legumes; the weak capacity of the roots of continuous monocrops to use water from deeper soil layers is the main reason for significant yield reduction or complete failure. This is the more significant in view of the likelihood of more severe droughts driven by global heating.

By including lucerne in rotation, it is possible to increase the amount of soil organic matter in deeper soil layers which, in turn, improves crop resilience to drought (Table 5).

Soil organic carbon (SOC) stocks have increased by $9.2 \mathrm{t} / \mathrm{ha}$ for the whole soil profile $(0-100 \mathrm{~cm})$ under the crop rotation with lucerne but have decreased by $4.2 \mathrm{t} / \mathrm{ha}$ for the crop rotation without lucerne. In both rotations, SOC stocks decreased in the upper soil layers 0-20 and $20-40 \mathrm{~cm}$. This phenomenon should be taken in consideration in agronomic research because, in most cases, SOC stocks are determined only for the upper soil layers and therefore do not reflect SOC changes over the whole soil profile. 
Table 3. Soil water accumulation $(\mathrm{mm})$ under corn-for-grain during the fall-winter-spring period in different crop rotations, continuous corn and in black fallow, average for 2006-2015, including in drought year of 2015, Selectia RIFC, Balti

\begin{tabular}{|c|c|c|c|c|c|}
\hline \multirow[b]{2}{*}{$\begin{array}{l}\text { Soil layers, } \\
\mathrm{cm}\end{array}$} & \multicolumn{3}{|c|}{ Crop rotation } & \multirow[b]{2}{*}{ Continuous corn } & \multirow[b]{2}{*}{$\begin{array}{c}\text { Permanent } \\
\text { black fallow }\end{array}$} \\
\hline & $70 \%$ row crops & $\begin{array}{l}60 \% \text { row crops }+ \\
12 \mathrm{t} / \mathrm{ha} \text { of manure }\end{array}$ & $\begin{array}{l}40 \% \text { row crops }+ \\
30 \% \text { lucerne }\end{array}$ & & \\
\hline \multicolumn{6}{|c|}{ Average 2006-2015 } \\
\hline $0-100$ & $61.1 / 49.6 \%$ & $77.4 / 67.8 \%$ & $76.9 / 55.1 \%$ & $53.9 / 51.0 \%$ & $28.8 / 57.6 \%$ \\
\hline $0-200$ & 123.2 & 114.1 & 139.5 & 105.6 & 50.0 \\
\hline \multicolumn{6}{|c|}{ In drought year 2015} \\
\hline $0-100$ & $118.5 / 66.1 \%$ & $115 / 73.7 \%$ & $139.9 / 55.8 \%$ & $66.1 / 62.5 \%$ & $38.3 / 79.8 \%$ \\
\hline $0-200$ & 179.3 & 156.0 & 250.5 & 105.7 & 48.0 \\
\hline
\end{tabular}

Table 4. Crop yields ( $\mathrm{t} / \mathrm{ha}$ ) in different crop rotations and in continuopus monocrops, average for 2000-2015, including drought years Data from long-term field experiments with crop rotations and continuous monocrops at Selectia RIFC, Balti

\begin{tabular}{|c|c|c|c|c|}
\hline \multirow[b]{2}{*}{ Crops } & \multicolumn{3}{|c|}{ Crop rotation } & \multirow{2}{*}{$\begin{array}{l}\text { Continuous } \\
\text { monocropping }\end{array}$} \\
\hline & $70 \%$ row crops & $\begin{array}{l}60 \% \text { row crops }+ \\
12 \mathrm{t} / \mathrm{ha} \text { of manure }\end{array}$ & $\begin{array}{c}40 \% \text { row crops }+ \\
30 \% \text { lucerne }\end{array}$ & \\
\hline \multicolumn{5}{|c|}{ Average for 2006-2015 } \\
\hline Winter wheat & 4.15 & 4.57 & 4.41 & 2.81 \\
\hline Corn-for-grain & 5.63 & 5.84 & 6.15 & 5.45 \\
\hline \multicolumn{5}{|c|}{ Drought year 2015} \\
\hline Winter wheat & 3.00 & 3.65 & 4.30 & 2.50 \\
\hline Corn-for-grain & 2.92 & 3.91 & 4.50 & 0 \\
\hline
\end{tabular}

Table 5. Changes in the stocks of soil organic carbon during 1992-2015 in crop rotation with and without lucerne on Typical chernozem of the Balti Steppe, t C/ha (mean of three replicates)

\begin{tabular}{|c|c|c|c|c|c|c|c|c|}
\hline \multirow{2}{*}{$\begin{array}{c}\text { Soil layers, } \\
\mathrm{cm}\end{array}$} & \multicolumn{4}{|c|}{ Crop rotation with lucerne } & \multicolumn{4}{c|}{ Crop rotation without lucerne } \\
\cline { 2 - 9 } & 1992 & 2015 & \pm & $\%$ & 1992 & 2015 & \pm & $\%$ \\
\hline $0-20$ & 71.0 & 59.0 & -12.0 & 17.3 & 66.7 & 52.6 & -14.1 & -21.1 \\
\hline $20-40$ & 69.6 & 63.9 & -6.0 & 8.6 & 62.9 & 56.4 & -6.5 & -10.3 \\
\hline $40-60$ & 56.2 & 61.6 & +5.4 & 9.6 & 51.5 & 52.5 & +1.0 & +1.9 \\
\hline $60-80$ & 37.2 & 52.9 & +15.7 & 42.2 & 31.1 & 38.1 & +7.0 & +22.5 \\
\hline $80-100$ & 37.0 & 43.1 & +6.1 & 16.5 & 19.3 & 27.7 & +8.4 & +43.5 \\
\hline $0-100$ & & & +9.2 & & & & -4.2 & \\
\hline
\end{tabular}

Table 6 presents SOC changes in unfertilized and fertilized plots in crop rotations, continuous monocrops and black fallow. SOC is decreasing in all experimental plots but the greatest loss of carbon was measured under continuous black fallow. Fertilization with organomineral fertilizers increases SOC relative to unfertilized plots. The content of SOC in crop rotation, especially in deeper soil layers, is lower in crop rotation than in continuous winter wheat and corn. The loss is determined by uncompensated losses of SOC by mineralization of soil organic matter associated with crop yield formation [6].

In the case of fertilized winter wheat and corn-forgrain grown in crop rotation, the share of soil fertility in yield formation is 88.5 and $100 \%$, respectively (Table 7). The share of soil fertility in yield formation is lower for continuous winter wheat and corn-for-grain: 64.9 and $67.6 \%$, respectively. For sugar beet and sunflower, the share of soil fertility in yield formation in crop rotation is $75.8 \%$ and $91.2 \%$, respectively. It decreases only for winter barley $59.6 \%$ (Table 8 ). The share of soil fertility in yield formation remains very high for sugar beet and sunflower even in continuous monocropping 72.5 and
87.0\%, respectively. Greater yields from crop rotation compared with continuous monocrops contribute to greater uncompensated losses of SOC through mineralization.

Crop rotations are less dependent on mineral fertilizers than continuous monocrops: under crop rotation, $\mathrm{N}$-use efficiency of winter wheat and corn for grain was $21.7 \%$ and zero, respectively.

$\mathrm{N}$ - use efficiency has also remained low for sunflower, both in crop rotation and continuous monocropping: 25.3 and $28.0 \%$, respectively (Table 8). $\mathrm{N}$ - use efficiency is higher for sugar beet and winter barley in crop rotation: 61.5 and $57.7 \%$, respectively. So, depending on the crop, between half of the applied mineral fertilizer and all of it is wasted.

The probability of $\mathrm{N}$ leaching is low because little or no water percolates through the deep subsoil to the watertable, but there is a narrow window early in the spring when it can happen. By respecting diverse crop rotations, it is possible to reduce the rates of mineral fertilizers, especially nitrogen, and pesticides for weed, pest and disease control. 
The lack of crop rotation in modern farming systems is compensated by higher rates of mineral fertilizers and pesticides. Elimination of perennial legumes from crop rotations and the associated demise of crop and animal husbandry mean a lack of farmyard manure, so and extensive areas under black fallow are paring away soil fertility - and with it provision of ecosystem services such as carbon capture, infiltration of rainfall and recharge of aquifers.

Sustainable agriculture cannot be achieved without restoration of soil fertility.

Table 6. Soil organic carbon $(\mathrm{C}, \%)$ in crop rotation, continuous monocropping and black fallow, 2015, Selectia RIFC

\begin{tabular}{|c|c|c|c|c|c|c|c|c|}
\hline \multirow{3}{*}{$\begin{array}{l}\text { Soil } \\
\text { layers, } \\
\mathrm{cm}\end{array}$} & \multirow{2}{*}{\multicolumn{2}{|c|}{$\begin{array}{l}\text { Crop rotation with } 60 \% \\
\text { row crops }\end{array}$}} & \multicolumn{4}{|c|}{ Continuous monocropping since 1965} & \multirow{2}{*}{\multicolumn{2}{|c|}{$\begin{array}{l}\text { Black fallow } \\
\text { since } 1965\end{array}$}} \\
\hline & & & \multicolumn{2}{|c|}{ Winter wheat } & \multicolumn{2}{|c|}{ Corn for grain } & & \\
\hline & Unfertilized & Fertilized & Unfertilized & Fertilized & Unfertilized & Fertilized & Unfertilized & Fertilized \\
\hline $0-20$ & 2.47 & 2.72 & 2.47 & 2.98 & 2.33 & 2.60 & 2.13 & 2.37 \\
\hline $20-40$ & 2.40 & 2.62 & 2.44 & 2.97 & 2.29 & 2.61 & 2.06 & 2.30 \\
\hline $40-60$ & 1.98 & 2.29 & 2.12 & 2.71 & 2.21 & 2.27 & 1.85 & 2.03 \\
\hline $60-80$ & 1.47 & 1.54 & 1.53 & 1.88 & 1.48 & 1.84 & 1.30 & 1.45 \\
\hline $80-100$ & 1.08 & 1.18 & 1.41 & 1.42 & 1.24 & 1.22 & 0.97 & 1.34 \\
\hline $0-100$ & 1.88 & 2.05 & 1.99 & 2.39 & 1.91 & 2.11 & 1.66 & 1.89 \\
\hline
\end{tabular}

Table 7. N- use efficiency (\%) by winter wheat and corn-for-grain grown in crop rotation and as continuous monocrops, average for 1994-2018, Selectia RIFC

\begin{tabular}{|c|c|c|c|c|c|c|c|c|c|}
\hline \multirow[b]{2}{*}{$\begin{array}{l}\text { Crop rotation, } \\
\text { continuous } \\
\text { monocropping }\end{array}$} & \multirow[b]{2}{*}{$\begin{array}{l}\text { Predeces- } \\
\text { sors }\end{array}$} & \multicolumn{2}{|c|}{ Fertilization } & \multirow{2}{*}{$\begin{array}{c}\text { Extra } \\
\text { yields } \\
\text { from } \\
\text { fertiliz., } \\
\text { t/ha }\end{array}$} & \multirow{2}{*}{$\begin{array}{c}\mathrm{N} \\
\text { taken } \\
\text { up by } \\
\text { extra } \\
\text { yield, } \\
\mathrm{kg} / \mathrm{ha}\end{array}$} & \multirow{2}{*}{$\begin{array}{l}\mathrm{N} \text { applied } \\
\text { with } \\
\text { mineral } \\
\text { fertilizers, } \\
\mathrm{kg} \text { a.i./ha }\end{array}$} & \multirow[b]{2}{*}{$\begin{array}{c}\text { N-use } \\
\text { efficiency } \\
\%\end{array}$} & \multirow{2}{*}{$\begin{array}{l}\text { Total N } \\
\text { uptake } \\
\text { on fert. } \\
\text { plots, } \\
\mathrm{kg} / \mathrm{ha}\end{array}$} & \multirow{2}{*}{$\begin{array}{c}\text { Share of } \\
\text { soil fertility } \\
\text { in yield } \\
\text { formation, } \\
\%\end{array}$} \\
\hline & & $\begin{array}{l}\text { Un- } \\
\text { fertil. }\end{array}$ & $\begin{array}{l}\text { Fert- } \\
\text { ilized }\end{array}$ & & & & & & \\
\hline \multicolumn{10}{|c|}{ Winter wheat } \\
\hline Crop rotation & $\begin{array}{l}\text { Oats-and- } \\
\text { vetch for } \\
\text { green } \\
\text { mass }\end{array}$ & 4.55 & 5.14 & +0.59 & 19.5 & 90 & 21.7 & 169.6 & 88.5 \\
\hline $\begin{array}{l}\text { Continuous } \\
\text { monocrop }\end{array}$ & $\begin{array}{l}\text { Winter } \\
\text { wheat }\end{array}$ & 1.96 & 3.02 & +1.06 & 35.0 & 90 & 38.9 & 99.7 & 64.9 \\
\hline \multicolumn{10}{|c|}{ Corn-for-grain } \\
\hline Crop rotation & Sugar beet & 5.54 & 6.06 & +0.52 & 12.0 & 0 & 0 & 139.4 & 100 \\
\hline $\begin{array}{l}\text { Continuous } \\
\text { monocrop }\end{array}$ & $\begin{array}{l}\text { Corn-for- } \\
\text { grain }\end{array}$ & 3.86 & 5.71 & +1.85 & 42.6 & 60 & 71.0 & 131.3 & 67.6 \\
\hline
\end{tabular}

Nitrogen is lost mainly as oxides of nitrogen, which are potent greenhouse gases.. Application of nitrogen from mineral fertilizers is problematic not only ecologically, but, also, economically in view of increasing fertilizer prices.
Taking into consideration the big share of soil fertility in yield formation, farmers should focus more on building soil fertility through proper management of soil organic matter. 
Table 8. $\mathrm{N}$ - use efficiency (\%) by sugar beet, sunflower and winter barley grown in crop rotation and in continuous monocropping, average for 1994-2018, Selectia RIFC

\begin{tabular}{|c|c|c|c|c|c|c|c|c|c|}
\hline \multirow{2}{*}{$\begin{array}{c}\text { Crop } \\
\text { rotation, } \\
\text { continuous } \\
\text { monocrops }\end{array}$} & \multirow[b]{2}{*}{$\begin{array}{c}\text { Predeces } \\
\text { sors }\end{array}$} & \multicolumn{2}{|c|}{ Fertilization } & \multirow{2}{*}{$\begin{array}{c}\text { Extra } \\
\text { yields } \\
\text { from } \\
\text { fertilizer } \\
\text { t/ha } \\
\end{array}$} & \multirow{2}{*}{$\begin{array}{l}\mathrm{N} \text { taken up } \\
\text { by extra } \\
\text { yield, } \\
\mathrm{kg} / \mathrm{ha}\end{array}$} & \multirow{2}{*}{$\begin{array}{l}\mathrm{N} \text { applied } \\
\text { with mineral } \\
\text { ferilizers, } \\
\mathrm{kg} / \mathrm{ha} \text { a.i./ha }\end{array}$} & \multirow[b]{2}{*}{$\begin{array}{c}\mathrm{N}-\text { use } \\
\text { efficien } \\
\text { cy, } \%\end{array}$} & \multirow{2}{*}{$\begin{array}{c}\text { Total N } \\
\text { uptake on } \\
\text { fertilized } \\
\text { plots, } \\
\mathrm{kg} / \mathrm{ha} \\
\end{array}$} & \multirow[b]{2}{*}{$\begin{array}{l}\text { Share of soil } \\
\text { fertility in } \\
\text { yield } \\
\text { formation, \% }\end{array}$} \\
\hline & & $\begin{array}{l}\text { Unfert } \\
\text { ilized }\end{array}$ & $\begin{array}{l}\text { Fertili } \\
\text { zed }\end{array}$ & & & & & & \\
\hline \multicolumn{10}{|c|}{ Sugar beet } \\
\hline $\begin{array}{c}\text { Crop } \\
\text { rotations }\end{array}$ & $\begin{array}{l}\text { Winter } \\
\text { wheat }\end{array}$ & 28.90 & 38.12 & +9.22 & 36.9 & 60 & 61.5 & 152.5 & 75.8 \\
\hline $\begin{array}{l}\text { Continuous } \\
\text { monocrops }\end{array}$ & $\begin{array}{c}\text { Sugar } \\
\text { beet }\end{array}$ & 7.81 & 14.92 & +7.11 & 16.4 & 60 & 27.3 & 59.7 & 72.5 \\
\hline \multicolumn{10}{|c|}{ Sunflower } \\
\hline $\begin{array}{c}\text { Crop } \\
\text { rotations }\end{array}$ & $\begin{array}{l}\text { Winter } \\
\text { wheat }\end{array}$ & 1.97 & 2.16 & +0.19 & 7.6 & 30 & 25.3 & 86.4 & 91.2 \\
\hline $\begin{array}{l}\text { Continuous } \\
\text { monocrops }\end{array}$ & $\begin{array}{c}\text { Sun } \\
\text { flower }\end{array}$ & 1.40 & 1.61 & +0.21 & 8.4 & 30 & 28.0 & 64.4 & 87.0 \\
\hline \multicolumn{10}{|c|}{ Crop rotations } \\
\hline $\begin{array}{c}\text { Crop } \\
\text { rotations }\end{array}$ & $\begin{array}{l}\text { Corn for } \\
\text { grain }\end{array}$ & 2.94 & 4.22 & +1.28 & 34.6 & 60 & 57.7 & 113.9 & 59.6 \\
\hline $\begin{array}{l}\text { Continuous } \\
\text { monocrops }\end{array}$ & $\begin{array}{l}\text { Winter } \\
\text { barley }\end{array}$ & 1.73 & 3.55 & +1.82 & 49.1 & 60 & 81.8 & 95.9 & 48.8 \\
\hline
\end{tabular}

\section{Conclusion}

1. Under steppe conditions, black fallow as predecessor for winter wheat gives no yield advantage compared with any other early-harvested predecessor. Moreover, it accumulates less soil water and increases losses of soil organic matter by mineralization.

2. Inclusion of perennial legumes in crop rotation contributes greater accumulation of soil organic matter and soil water in the deeper soil layers - thereby lending greater resilience to drought.

3. Yields of winter wheat and corn-for-grain are bigger and more reliable in crop rotation with perennial legumes compared with rotations without legumes and, especially, compared with continuous monocropping.

4. The share of soil fertility in yield formation for fertilized winter wheat and corn-for-grain in crop rotation averaged 88.5 and $100 \%$, respectively for $1994-$ 2018-. In contrast, the share of soil fertility in yield formation on fertilized plots for continuous winter wheat and corn-for-grain was 64.9 and $67.6 \%$, respectively.

5. The share of soil fertility in yield formation for fertilized sugar beet, sunflower and winter barley in crop rotation averaged 75.8; 91.2 and $59.6 \%$, respectively for the same period. The share of soil fertility in yield formation on fertilized plots for continuous sugar beet, sunflower and winter barley for the same period of time were $72.5 ; 87.0$ and $48.8 \%$, respectively.

6. $\mathrm{N}-$ use efficiency from nitrogen mineral fertilizers is relatively low (from 0 up to $50 \%$ depending on crops), which makes their application problematic from both the ecological and economic perspective. Building soil fertility through a proper management of soil organic matter makes good sense.

7. A diverse crop rotation that restores soil fertility means less dependence on industrial inputs and their derivatives and greater resilience against drought.

\section{References}

1. The future of food and agriculture. Trends and challenges (FAO, Rome, 2017)

2. Agriculture at a Crossroads. International Assessment of Agricultural Knowledge, Science and Technology for Development Synthesis Report (The World Bank, Washington DC, 2009)

3. The future of Food and Farming. Challenges and choices for global sustainability Foresight, Final Project Report (Government Office for Science, London, 2011)

4. I.A. Krupenikov, B.P. Boincean, D.L. Dent, The Black Earth. Ecological principles for sustainable agriculture on Chernozem soils (Springer, Dordrecht, 2011)

5. D.L. Dent (editor), Soil as World Heritage (Springer, Dordrecht, 2014)

6. B.P. Boincean, D.L. Dent, Farming the Black Earth. Sustainable and Climate - Smart Management of Chernozem Soils (Springer Nature, Cham, 2019) 